\title{
EFEKTIVITAS CAISIN SEBAGAI TANAMAN PERANGKAP PATOGEN UNTUK PENGENDALIAN PENYAKIT AKAR GADA PADA KUBIS
}

\author{
Hadiwiyono, Sholahuddin \& Endang Sulastri \\ Program Studi Agroteknologi Fakultas Pertanian Universitas Sebelas Maret \\ Jl. Ir. Sutami 36A Kentingan Surakarta 57126. Telp/Faks. 0271637457 \\ E-mail: hadi_hpt@yahoo.com
}

\begin{abstract}
Effectiveness of chines cabbage as trap crop of the pathogen for control clubroot of cabbage. The research was conducted by observation on 5 plot kinds of cabbage planting. The plots consist of control plot with no planting Chinese cabbage, plot with planting Chinese cabbage as rotation plant on 38 day before planting of cabbage followed by manual eradication, plot with planting Chinese cabbage as rotation plant on 38 day followed by flooding for 14 days and soil tillage, plot with mixcropping Chinese cabbage on the early growth stage of the cabbage, and plot with intercropping of Chinese cabbage on 14 days before planting the cabbage. The results showed that planting Chinese cabbage as trap crop of the pathogen followed by eradication of the infected Chinese cabbage effectively controlled clubroot intensity and significantly restored the partial yields of the cabbage.
\end{abstract}

Keywords : cabagge, chinese cabbage, clubroot, eradication, trap crop

\begin{abstract}
ABSTRAK
Efektivitas caisin sebagai tanaman perangkap patogen untuk pengendalian penyakit akar gada pada kubis. Penelitian ini dilaksanakan melalui observasi pada 5 macam plot pertanaman kubis. Plot terdiri dari plot kontrol tanpa penanaman caisin, plot dengan penanaman caisin sebagai tanaman rotasi pada 38 hari sebelum penanaman kubis yang diikuti dengan eradikasi manual, plot dengan penanaman caisin sebagai tanaman rotasi pada 38 hari sebelum penanaman kubis yang diikuti dengan pengenangan lahan selama 14 hari dan pengolahan tanah, plot dengan penanaman caisin secara campuran pada awal pertumbuhan kubis, dan plot dengan penanaman caisin secara tumpanggilir pada 14 hari sebelum tanam kubis. Hasil penelitian menunjukkan bahwa penanaman caisin sebagai tanaman perangkap diikuti dengan eradikasi caisin terinfeksi, efektif mengendalikan intensitas penyakit akar gada dan mengembalikan kehilangan hasil kubis secara berarti.
\end{abstract}

Kata Kunci: akar gada, caisin, eradikasi, kubis, tanaman perangkap

\section{PENDAHULUAN}

Kubis (Brassica oleracea L) merupakan sayuran penting bagi petani dan masyarakat di Indonesia, karena menjadi sumber gizi, pendapatan petani, dan devisa bagi negara. Sayuran kubis banyak mengandung vitamin, mineral, dan antioksidan yang vital dibutuhkan masyarakat (Permadi, 1993; Pracaya, 2005; Cahyono, 2008). Budidaya kubis dapat meningkatkan pendapatan petani, karena bernilai ekonomi tinggi. Menurut Cahyono (2008) Benefit cost ratio (B/C ratio) dan return of investment (ROI) hasil analisis usaha tani kubis menunjukkan angka yang signifikan yaitu berturut-turut 3,54 dan 233,41\%. Kubis juga berperan sebagai komoditas ekspor sehingga dapat menjadi sumber devisa bagi negara. Sebagai komoditas ekspor, volume ekspor kubis selalu terbesar dibandingkan sayuran yang lain (Cahyono, 2008). Oleh karena itu, tidak salah ketika pemerintah sangat peduli untuk mengembangkan kubis baik untuk meningkatkan pendapatan petani, memenuhi permintaan masyarakat sendiri, ataupun untuk meningkatkan pendapatan devisa negara melalui ekspor kubis.

Meskipun demikian, dalam pengembangannya petani dihadapkan pada kendala usaha tani kubis yang salah satunya adalah berupa serangan hama dan patogen penyebab penyakit. Salah satu penyakit yang penting adalah akar gada (clubroot) yang disebabkan oleh Plasmodiphora brassicae Wor. Penyakit ini tersebar luas di Indonesia (Cicu, 2006) dan bahkan di berbagai belahan dunia, tempat kekubisan dibudidayakan (Dixon, 2009; Donald \& Porter, 2009; Howard et al., 2010; 
Miller et al., 2010). Patogen ini menyerang dan merusak perakaran kubis sehingga tanaman menjadi terhambat pertumbuhannya atau mati.

Di lapangan, tidak jarang patogen menyebabkan puso sehingga petani gagal panen 100\% (Hadiwiyono \& Supriyadi, 1998).

Pada lahan yang telah terkontaminasi patogen, penyakit ini sukar dikendalikan karena patogen dapat bertahan selama bertahun-tahun dalam tanah meskipun tanpa tanaman inang (Dixon, 2009). Oleh karena itu, tindakan pengendalian untuk disinfestasi patogen pada lahan terkontaminasi merupakan komponen penting dalam pengelolaan penyakit akar gada secara terpadu (Donald \& Porter, 2009). Salah satu teknik disinfestasi patogen pada lahan terkontaminasi patogen adalah melalui penanaman tanaman perangkap (trap crop). Penggunaan tanaman perangkap untuk pengendalian hama telah lama diterapkan dan pada beberapa kasus dapat berhasil dengan sangat baik (Shelton \& BadenesPerez, 2006), namun penerapannya untuk pengendalian penyakit masih sulit ditemukan. Tanaman perangkap untuk pengendalian patogen diartikan sebagai tanaman yang rentan terhadap infeksi awal patogen tetapi kemudian patogen tidak dapat menyelesaikan perkembangannya, karena tanaman bersifat tahan atau dipanen sebelum patogen dapat menyelesaikan perkembangannya (Maloy, 1993).

Caisin (Brassica chinensis L) berpotensi sebagai tanaman perangkap patogen akar gada, karena tanaman ini rentan terhadap patogen akar gada dan dapat dipanen pada umur 25-40 hari setelah sebar benih, sehingga saat dipanen patogen belum dapat menyelesaikan proses infeksinya. Oleh karena itu, apabila penanaman caisin pada lahan terkontaminasi patogen yang disertai eradikasi tanaman terinfeksi akan menurunkan populasi patogen. Caisin yang terinfeksi umumnya masih dapat dipanen tanpa penurunan kualitas yang berarti, sehingga di samping dapat sebagai tanaman perangkap patogen akar gada caisin dapat menambah penghasilan patani (Hadiwiyono, 1999). Namun demikian, baik kajian maupun penerapan caisin sebagai tanaman perangkap patogen akar gada belum dilakukan. Penelitian ini bertujuan untuk mengevaluasi efektivitas caisin (B. chinensis) sebagai tanaman perangkap patogen untuk mengendalikan penyakit akar gada pada budidaya kubis pada lahan terkontaminasi berat patogen.

\section{METODE PENELITIAN}

Penelitian ini dilaksanakan pada bulan Agustus sampai November 2009, di lahan yang terkontaminasi berat patogen akar gada di daerah Ngargoyoso Karanganyar dengan ketinggian $800 \mathrm{~m}$ di atas permukaan laut. Tingkat kontaminasi lahan didasarkan pada tingkat infeksi tanaman rentan terhadap patogen sebagai indikator (Pandolfini et al., 1997). Pada penelitian ini digunakan caisin sebagai tanaman indikator. Lahan terkontaminasi berat kejadian penyakit akar gada pada tanaman indikator (caisin) mencapai sama atau lebih dari 90\%. Infeksi patogen pada tanaman indikator didasarkan gejala akar gada pada akar caisin yang dicabut pada umur 38 minggu. Hasil pengamatan insidens penyakit akar gada pada caisin indikator pada lahan percobaan diperoleh hasil rata-rata $95 \pm 2,5 \%$.

\section{Rancangan Penelitian}

Plot pengujian. Penelitian ini dilaksanakan dengan observasi pada 5 macam plot pengujian pertanaman kubis dengan varietas KK Cross sebagai tanaman pokok dan caisin varietas Bangkok sebagai tanaman perangkap. Setiap unit pengujian merupakan pertanaman kubis seluas $100 \mathrm{~m}^{2}$ yang antarplot pengujian diatur secara acak lengkap. Lima macam plot pengujian yang dimaksud adalah tanpa penanaman caisin, penanaman caisin sebagai tanaman rotasi 38 hari sebelum tanam kubis disertai eradikasi manual terhadap caisin terinfeksi, penanaman caisin sebagai tanaman rotasi 38 hari sebelum tanam kubis disertai eradikasi dengan pengolahan tanah dan perendaman lahan selama 14 hari sebelum tanam kubis, penanaman caisin secara campuran di awal pertumbuhan kubis, dan penanaman caisin secara tumpang gilir 14 hari sebelum tanam kubis.

Cara tanam kubis dan caisin. Bibit kubis yang digunakan merupakan bibit hasil pembibitan pada plastik polibag berdiameter $5 \mathrm{~cm}$ dan tinggi $10 \mathrm{~cm}$ berisi tanah steril campur kompos dengan perbandingan volume 2:1. Sterilisasi tanah dilakukan dengan pelakuan uap panas dengan cara mengukus dalam drum selama 30 menit yang diulang 3 kali. Bibit dipindahtanamkan ke lahan pada umur 28 hari setelah pengecambahan. Kubis ditanam dengan jarak $50 \times 50 \mathrm{~cm}$ pada bedengan dengan tinggi $\pm 30 \mathrm{~cm}$ dan lebar $70 \mathrm{~cm}$ dan jarak antarbedang 30 cm (Pracaya, 2005; Cahyono, 2008). Caisin ditanam dengan cara tabur langsung pada bedengan dengan jarak $\pm 10 \mathrm{~cm}$.

\section{Variabel Pengamatan}

Penentuan tanaman sampel. Pengamatan keparahan penyakit dan berat krop dilakukan terhadap 3 kelompok tanaman sampel per plot yang ditentukan secara sistematik dengan pola segitiga. Setiap kelompok 
berjumlah 10 tanaman kubis (setara $3 \mathrm{~m}^{2}$ luas lahan) untuk pengamatan variabel penyakit dan hasil kubis.

Variabel penyakit. Variabel pengamatan penyakit meliputi luas bawah kurva perkembangan penyakit (LBKPP), keparahan penyakit dan nilai efektivitas pengendalian penyakit. LBKPP dihitung dengan rumus sebagai berikut (Campbell, 2008).

$$
\operatorname{LBKPP}=\sum_{n-1}^{\mathrm{i}=1}\left[\frac{\mathrm{x}_{\mathrm{i}}+\mathrm{X}_{\mathrm{i}+1}}{2}\right] \times \mathrm{t}_{\mathrm{i}+1}-\mathrm{t}_{\mathrm{i}}
$$

dengan $\mathrm{X}$ = insidens penyakit dan $\mathrm{t}$ = waktu pengamatan . Insidens penyakit didasarkan pada pengamatan visual gejala kelayuan kubis di atas tanah di sekitar jam 12 siang yang dilakukan mingguan secara periodik. Insidens penyakit merupakan persentase tanaman layu dari $10 \mathrm{x}$ 10 kelompok tanaman sampel yang ditentukan secara sistematik secara siksak antarbedeng dari sepuluh bedeng tengah plot pengujian.

Keparahan penyakit dihitung dengan metode skor dengan skala kerusakan akar 0 sampai 5. Penentuan skala kerusakan akar dilakukan dengan cara mencabut tanaman pada saat dipanen. Pengukuran keparahan penyakit diukur dengan rumus sebagai berikut:

$$
\mathrm{KP}=\frac{\sum(\mathrm{n} \times \mathrm{v})}{\mathrm{N} \times \mathrm{V}} \times 100 \%
$$

dengan $\mathrm{KP}=$ keparahan penyakit, $\mathrm{n}=$ jumlah tanaman sakit menunjukkan skor tertentu, $\mathrm{v}=$ skor untuk tanaman sakit, $\mathrm{N}=$ jumlah seluruh tanaman yang diamati, dan $\mathrm{V}=$ skor tertinggi yang digunakan. Adapun skor yang digunakan adalah $0=$ tidak ada serangan, $1=$ kerusakan akar 1-20\%, 2 = kerusakan akar 21-40\%, $3=$ kerusakan akar 41-60\%, 4 = kerusakan akar 61-80\%, dan 5 = kerusakan akar lebih dari 80\% (Hadiwiyono, 1999). Nilai efektivitas pengendalian penyakit akar gada dihitung dengan rumus sebagai berikut:

$$
\mathrm{NE}=\frac{\mathrm{e}_{1}-\mathrm{e}_{2}}{\mathrm{e}_{1}} \times 100 \%
$$

dengan $\mathrm{NE}=$ nilai efektivitas pengendalian, $\mathrm{e}_{1}=$ keparahan penyakit pada plot kontrol tanpa pengendalian, dan $\mathrm{e}_{2}=$ keparahan penyakit pada plot perlakuan.

Variabel hasil kubis. Variabel hasil kubis yang diamati adalah hasil kubis per hektar, nilai peningkatan hasil kubis, dan berat krop. Hasil kubis per hektar dikonversi dari petak sampel seluas $9 \mathrm{~m}^{2}$ (3 $\mathrm{m}^{2} \mathrm{x} 3$ petak sampel). Peningkatan hasil kubis per hektar dihitung dengan rumus sebagai berikut:

$$
\mathrm{PH}=\frac{\mathrm{h}_{2}-\mathrm{h}_{1}}{\mathrm{~h}_{2}} \times 100 \%
$$

dengan $\mathrm{PH}=$ nilai peningkatan hasil kubis, $\mathrm{h}_{2}=$ hasil kubis per hektar pada plot perlakuan, dan $\mathrm{h}_{1}=$ hasil per hektar pada plot kontrol tanpa pengendalian. Berat krop kubis per tanaman dihitung rata-rata dari 30 tanaman sampel dari 3 kelompok sampel (3 x 10 tanaman) dari sampel yang sama untuk pengukuran keparahan penyakit.

\section{HASIL DAN PEMBAHASAN}

Penanaman caisin sebagai tanaman perangkap patogen yang disertai eradikasi, terbukti efektif dapat menurunkan serangan patogen akar gada (Tabel 1) sehingga dapat meningkatkan hasil kubis sebagai tanaman pokok (Tabel 2). Namun demikian, penanaman caisin sebagai perangkap patogen yang tidak disertai eradikasi tanaman perangkap yang terinfeksi tidak efektif menurunkan serangan patogen akar gada.

Penanaman caisin sebagai tanaman rotasi 38 hari sebelum tanam kubis disertai eradikasi dengan perendaman lahan selama 14 hari memberikan hasil terbaik dalam menurunkan LBKPP dan keparahan penyakit akar gada dengan nilai efektivitas pengendalian paling tinggi, yaitu 57,78\%. Hal ini menunjukkan bahwa perlakuan tersebut paling efektif dalam disinfestasi propagul patogen akar gada pada tanah. Keefektivan tersebut juga ditunjukkan dengan hasil kubis per hektar yang tertinggi dengan nilai peningkatan hasil 29,67\% dibandingkan tanpa pengendalian dan berat krop per tanaman rata-rata yang tertinggi yaitu $1,18 \mathrm{~kg}$.

Pengendalian yang efektif kedua adalah penanaman caisin sebagai tanaman rotasi sampai 38 hari dan diikuti eradikasi secara manual. Perlakuan ini memberikan nilai efektivitas sebesar 17,78\% dan dapat meningkatkan hasil 16,84\%. Penanaman caisin secara campuran ataupun tumpanggilir di awal pertumbuhan kubis yang tidak disertai eradikasi efektif dapat menurunkan LBKPP, namun tidak menurunkan keparahan penyakit akhir dan malahan lebih tinggi daripada kontrol. Penanaman caisin yang tidak diikuti dengan eradikasi meningkatkan inokulum patogen yang kemudian menginfeksi kubis pada akhir pertumbuhan. Hal ini ditunjukkan adanya gejala sekunder berupa puru 
Tabel 1. Pengaruh penanaman caisin sebagai tanaman perangkap patogen dan eradikasinya terhadap LBKPP, keparahan penyakit, dan nilai efektivitas pengendalian akar gada

\begin{tabular}{llrcc}
\hline \multicolumn{1}{c}{$\begin{array}{c}\text { Penanaman } \\
\text { Caisin }\end{array}$} & \multicolumn{1}{c}{ Eradikasi Caisin } & LBKPP & $\begin{array}{c}\text { Keparahan } \\
\text { penyakit (\%) }\end{array}$ & $\begin{array}{c}\text { Nilai efektivitas } \\
\text { pengendalian (\%) }\end{array}$ \\
\hline Tanpa & Tanpa & $138,25 \pm 6,66 \mathrm{~d}$ & $45,00 \pm 2,40 \mathrm{c}$ & - \\
38 HST (rotasi) & Cabut manual & $61,25 \pm 3,64 \mathrm{a}$ & $37,00 \pm 0,79 \mathrm{~b}$ & 17,78 \\
38 HST (rotasi) & Lahan direndam 14 hari & $83,13 \pm 2,78 \mathrm{~b}$ & $19,00 \pm 0,78 \mathrm{a}$ & 57,78 \\
0 HST (campuran) & Tanpa & $105,00 \pm 3,35 \mathrm{c}$ & $45,00 \pm 0,57 \mathrm{c}$ & 0,00 \\
14 HST (tumpanggilir) & Tanpa & $66,50 \pm 1,56 \mathrm{a}$ & $61,00 \pm 0,79 \mathrm{~d}$ & 0,00 \\
\hline
\end{tabular}

HST: hari sebelum tanam kubis, LBKPP: luas bawah kurva perkembangan penyakit, angka rata-rata pada kolom sama yang diikuti huruf sama tidak berbeda nyata pada taraf $5 \%$.

Tabel 2. Pengaruh penanaman caisin sebagai tanaman perangkap patogen beserta eradikasinya terhadap hasil, peningkatan hasil, dan berat krop kubis

\begin{tabular}{llccc}
\hline $\begin{array}{c}\text { Penanaman } \\
\text { Caisin }\end{array}$ & \multicolumn{1}{c}{ Eradikasi Caisin } & $\begin{array}{c}\text { Hasil kubis } \\
\text { (ton ha-1) }^{-1}\end{array}$ & $\begin{array}{c}\text { Nilai Peningkatan } \\
\text { hasil kubis }(\%)\end{array}$ & $\begin{array}{c}\text { Berat krop Kubis } \\
\text { (kg per tanaman) }\end{array}$ \\
\hline Tanpa & Tanpa & $27,30 \pm 1,06 \mathrm{a}$ & - & $0,91 \pm 0,18 \mathrm{a}$ \\
38 HST (rotasi) & Cabut manual & $31,90 \pm 3,25 \mathrm{~b}$ & 16,84 & $1,13 \pm 0,23 \mathrm{~b}$ \\
38 HST (rotasi) & Lahan direndam 14 hari & $35,40 \pm 7,56 \mathrm{c}$ & 29,67 & $1,18 \pm 0,35 \mathrm{c}$ \\
0 HST (campuran) & Tanpa & $30,90 \pm 3,56 \mathrm{~b}$ & 13,19 & $1,03 \pm 0,22 \mathrm{~b}$ \\
14 HST (tumpanggilir) & Tanpa & $26,70 \pm 2,99 \mathrm{a}$ & 0,00 & $0,89 \pm 0,29 \mathrm{a}$ \\
\hline
\end{tabular}

HST: hari sebelum tanam kubis, angka rata-rata pada kolom sama yang diikuti huruf sama tidak berbeda nyata pada taraf $5 \%$.

yang masih berkembang dan belum pecah saat kubis dipanen.

Hasil penelitian ini membuktikan bahwa caisin bersifat rentan terhadap infeksi patogen akar gada dan dapat menjadi tanaman perangkap patogen tersebut. Hal ini karena caisin dapat merangsang perkecambahan spora rehat patogen akar gada. Spora rehat patogen akar gada dapat terpacu untuk berkecambah oleh eksudat yang dikeluarkan tanaman inang yang rentan atau tanaman bukan inang tertentu (Friberg et al., 2005; 2006; Howard et al., 2010). Spora rehat yang terimbas berkecambah di daerah rizosfer tanaman rentan secara aktif mendekati jaringan rambut akar untuk melakukan penetrasi dan kemudian menginfeksi tanaman (Howard et al., 2010; Kageyama \& Asano, 2009).

Proses infeksi patogen akar gada pada bibit sampai sporulasi, membutuhkan waktu sedikitnya 5560 hari, sehingga apabila caisin terinfeksi dilakukan eradikasi pada umur panen caisin 38 hari setelah tanam maka patogen akan mati sebelum menyelesaikan siklus untuk membentuk generasi baru dengan sporulasi (Hadiwiyono \& Supriyadi, 1998). Eradikasi manual dengan cara mencabut akar untuk dihancurkan, menyebabkan patogen yang menginfeksi akar ikut terangkat dan terhancurkan. Penurunan populasi propagul patogen akar gada dalam tanah ditunjukkan adanya penurunan serangan patogen akar gada pada kubis sebagai tanaman pokok.

Hasil penelitian menunjukkan bahwa penanaman caisin yang disertai eradikasi dengan perendaman lahan sebelum tanam kubis efektif menurunkan serangan patogen akar gada. Hal ini diduga bahwa disinfestasi tidak saja melalui tanaman perangkap caisin, namun kondisi anaerob perendaman juga ikut terlibat pada disinfestasi patogen tersebut. Hasil ini sesui dengan penelitian sebelumnya bahwa kondisi anaerob pada sisa tanaman terinfeksi patogen akar gada menyebabkan populasi patogen menurun drastis (Hadiwiyono et al., 2000). Kondisi anaerob selama proses pengomposan bahan tanaman terinfeksi juga telah banyak dilaporkan 
efektif mendisinfestasi patogen yang terbawa tanaman terinfeksi tersebut (Fayolle et al., 2006).

Pada hasil penelitian ini, perendaman lahan menyebabkan kondisi tanah menjadi anaerob sehingga dapat mengubah struktur komunitas mikroba termasuk antagonis. Mikroba aerob termasuk jamur dan bakteri patogen akan mengalami peningkatan respirasi sebagai akibat kekurangan oksigen sehingga patogen segera mati karena kehabisan energi (Goud et al., 2004; Sessiha et al., 2007). Oleh karena itu, kondisi anaerob secara langsung dapat menurunkan populasi patogen dan tidak langsung melalui aktivasi mikroba antagonis khususnya dari mikroba anaerab. Goud et al. (2004) melaporkan bahwa pengkondisian anaerob dalam waktu tertentu efektif dapat menurunkan propagul patogen Verticillium dahliae, sedangkan menurut Sessiha et al. (2007) cara ini efektif untuk disinfestasi lahan dari patogen busuk cokelat kentang, Ralstonia solanacearum ras 3 biovar 2. Namun demikian, perendaman ini dapat menurunkan kesupresifan hayati tanah terhadap patogen tertentu, sebagai akibat mikroba yang berperan pada kesupresifan tanah menurun (van Os et al., 1999).

Penanaman caisin sebagai tanaman campuran di awal pertumbuhan kubis dan tumpang gilir yang tidak disertai eradikasi caisin terinfeksi, efektif dapat menurunkan LBKPP, namun keparahan penyakit akhir tanam tetap tinggi. Penurunan LBKPP disebabkan oleh propagul patogen akar gada yang terperangkap menginfeksi caisin pada awal pertumbuhan kubis, namun karena tidak disertai eradikasi tanaman perangkap, patogen dapat menyelesaikan siklus infeksi dan sporulasi sehingga populasi patogen meningkat. Peningkatan populasi ini meningkatkan keparahan akar gada di akhir pertumbuhan sehingga saat panen keparahan penyakit pada kubis sebagai tanaman pokok meningkat. Hasil ini sesui dengan pendapat Shelton \& Badenes-Perez (2006) bahwa risiko penggunaan tanaman rentan sebagai perangkap patogen adalah apabila siklus patogen lebih cepat bersporulasi sebelum dieradikasi, sehingga patogen menghasilkan generasi baru yang dapat meningkatkan populasi patogen.

\section{SIMPULAN}

Hasil penelitian menunjukkan bahwa penanaman caisin sebagai tanaman perangkap patogen disertai eradikasi tanaman efektif dalam menurunkan intensitas penyakit sehingga mampu meningkatkan hasil kubis. Selanjutnya, praktik bertanam kubis dengan penanaman caisin sebagai tanaman perangkap disertai eradikasi caisin terinfeksi dapat dipertimbangkan sebagai komponen dalam pengelolaan penyakit akar gada secara terpadu. Namun demikian, eradikasi caisin sebagai tanaman perangkap harus dilakukan secara efektif untuk menghindari risiko caisin terinfeksi patogen yang berkembang menjadi sumber inokulum.

\section{SANWACANA}

Penelitian ini merupakan bagian dari penelitian payung "Perakitan Paket Teknologi Pengelolaan Hama Terpadu dalam Upaya Mengembalikan Kubis sebagai Komoditas Unggulan di Karanganyar” didanai dari sumber dana Hibah Strategis Nasional DP3M DIKTI Tahun Anggaran 2009 melalui Kontrak No:0162.0/02304.2/XIII/2009.

\section{DAFTAR PUSTAKA}

Cahyono B. 2008. Cara Meningkatkan Budidaya Kubis. Yayasan Pustaka Nusatama, Yogjakarta.

Campbell CL. 1998. Disease progress in time: modeling and data analysis. Pp. 181-204 In: DG Jones, eds. The Epidemiology of Plant Diseases. Kluwer Academic Publishers, Dordrecht.

Cicu. 2006. Penyakit akar gada (Plasmodiophora brassicae Wor.) pada kubis-kubisan dan upaya pengendaliannya. J. Litbang Pert. 25(1): 1621.

Dixon GR. 2009. The occurrence and economic impact of clubroot disease. J. Plant Growth Regul. 28: 194-202.

Donald C \& Porter I. 2009. Integrated control of club root. J. Plant Growth Regul. 28: 289-303.

Fayolle L, Nobel R, Coventry E, Aime S \& Alabouvette C. 2006. Eradication of during composting of wastes. Plant Pathol. 55: 553-558.

Friberg H, Lagerlof J \& Ramert B. 2005. Germination of resting spores stimulated by a non-host plant. Eur. J. Plant Pathol. 113: 275-281.

Friberg H, Lagerlof J \& Ramert B. 2006. Usefulness of nonhost plants in managing Plasmodiophora brassicae. Plant Pathol. 55: 690-695. 
Goud JKC, Termorshuizen AJ, Blok WJ \& van Buggen AHC. 2004. Long-term effect of biological soil disinfestations on verticillium wilt. Plant Disease 88(7): 688-694.

Hadiwiyono. 1999. Jamur akar gada (Plasmodiophora brassicae Wor.): uji toleransi inang dan pengendaliannya secara hayati dengan Trichoderma. Pp. 365-371 Dalam: Soedarmono T, Arwiyanto T, Donowidjojo S, Djatmiko HA, Utami DS, Prihatiningsih N, Pramono E, Manan A \& Mugiastuti E, Penyunting. Prosiding Kongres Nasional XV dan Seminar Ilmiah Perhimpunan Fitopatologi Indonesia, Purwokerto, 16-18 September 1999.

Hadiwiyono \& Supriyadi. 1998. Penyakit "menthol" sebagai pengganggu baru kubis-kubisan di Tawangmangu, Karanganyar. Caraka Tani 13(2): 16-24.

Hadiwiyono, Pujiasmanto B \& Rahayu M. 2000. Pengaruh fermentasi dalam air sisa tanaman sakit terhadap propogul patogen akar gada (Plasmodiophora brassicae Wor.) dan penggunaannya sebagai pupuk caisin (Brassica chinensis L). Agrosains 2(1): 23-29.

Howard RJ, Strelkov SE \& Harding MW. 2010. Clubroot of cruciferous crops - new perspectives on an old disease. Can. J. Plant Pathol. 32(1): 43-57.

Kageyama K \& Asano T. 2009. Life cycle of Plasmodiophora brassicae Wor. J. Plant Growth Regul. 28(3): 203-211.

Miller SA, Rowe RC \& Riedel RM. 2010. Club root on crucifers. The Ohio State University, Ohio. http://ohioline.osu.edu/hyg-fact/3000/pdf/ 3118.pdf. Accessed: August 8 ${ }^{\text {th }}, 2010$.

Maloy CO. 1993. Plant Diseases: Priciples and Pactices. John Wiley \& Sons Inc., New York.

Pandolfini T, Gremigni P \& Gabbrielli R. 1997. Biomonitoring of soil health by plants. Pp. 325348 In: Pankhurst CE, Doube BM \& Gupta VVSR, eds. Biological Indicator of Soil Health. CAB International Publishing, UK.

Permadi AH. 1993. Budidaya kubis. Hal. 23-38 Dalam: Permadi AH \& Sastrosiswojo, Penyunting. Kubis. Badan Penelitian dan Pengembangan Pertanian, Balai Penelitian Tanaman Hortikultura, Lembang.

Pracaya. 2005. Kol alias Kubis. Penebar Swadaya, Jakarta.

Sessiha NAS, van Diepeningen AD, Wenneker M, van Beuningen AR, Janse JD, Coenen TGC, Termorshuizen AJ, van Bruggen AHC \& Blok WJ. 2007. Biological soil disinfestations (BSD), a new control method for potato brown rot, caused by Ralstonia solanacearum race 3 biovar 2. Europ. J. Plant Pathol. 117(4): 403415.

Shelton AM \& Badenes-Perez FR. 2006. Concepts and applications of trap cropping in pest management. Ann. Rev. Entomol. 51: 285-309.

van Os GJ, Wijnker JPM \& van Gulik WJM. 1999. Effects of soil fumigation and flooding on suppression of Pythium root rot in ornamental bulb culture. Eur. J. Plant Pathol. 105: 791-800. 